\section{SELECT COMMITTEE}

\section{All Well at NIO}

THe healthy state of British oceanography was extolled again last week when the Select Committee on Science and Technology continued its investigation of the Natural Environment Research Council. Attention focused on the National Institute of Oceanography, represented by its director, Dr G. E. R. Deacon, and the Committee on Marine Technology represented by its chairman, Mr W. J. Charnley from the Ministry of Technology. Both seem to be happy with their organizations and see no need for any changes.

NERC chose the National Institute of Oceanography (NIO) as an important case for expansion in its scheme to extend the scope of physical oceanography in Britain, but the institute cannot grow much more now. Dr Deacon said that he requires perhaps another thirty or forty people to add to the present 250 or so scientists and technical staff. People devoted to marine science are apparently hard to find, and recruiting suitable scientists and engineers has to be a long and careful process. Technical staff are equally difficult to find because they can earn more on the underground railway. NIO is not a victim of the brain drain, Dr Deacon said. Although some of his staff have gone to the United States, they have always returned because they find less competition for facilities in Britain.

Relations with the universities seem to be most amicable. There are many visits and exchanges, as well as joint seminars with Cambridge, Reading and Southampton Universities, and NIO also lends apparatus and provides ship time for university work. Dr Deacon said that great care will be taken to avoid duplication of work at NIO and the Institute of Coastal Oceanography and Tides at Liverpool. NERC's Oceanography and Fisheries Committee takes care of coordination between the various institutes, and does it very efficiently as its chairman, Professor M. J. Lighthill, pointed out.

Collaboration extends beyond the bounds of NERC, for Dr Deacon explained that NIO works closely with the Admiralty, although carrying out no formal work for the Navy. He was sure that the Navy knows everything that goes on in his laboratory, and equally he knows what is happening in unclassified naval research. No classified work is done at $\mathrm{NIO}$; the programme is determined entirely according to civil needs, and any advantage to defence research is incidental.

Mr Charnley explained the role of the Committee on Marine Technology in encouraging promising research projects. The committee's functions are, first, to identify economically promising projects, and second, to stimulate people to make use of the fruits of the research. Representatives on the committee are from the Ministry of Technology, NLRC, the Ministry of Defence, the Navy and the National Research and Development Corporation. Mr B. Parkyn was surprised by the absence of industrial representation. $\mathrm{Mr}$ Charnley explained that questions of commercial exploitation are taken up individually with the industries concerned. It would not be possible to gain the essential confidence of all sections of industry if some, but not others, were represented on the committee.

Mr Charnley was very satisfied with the first year's progress of his committee, which was set up as a result of the recommendation of the recent white paper on marine science and technology. Nobody could explain why the white paper has only just been published although the Committee on Marine Technology has been in existence for a year and is now due to report to the Cabinet Office. The origin of this relationship lies in the fact that in the summer of 1967 the Cabinet Office convened a committee, under Dr F. H. Allen, which subsequently produced the white paper.

Neither Mr Charnley nor Professor Lighthill could see any reason for changing the present organization of British oceanography in spite of the apparent plethora of committees reporting to different masters. They felt that NERC is not yet old enough for changes to be useful, for it is bound to take three or four years to learn to operate any new system. If there is any weakness it is lack of manpower and finance.

\section{Parliament in Britain}

\section{Rubella Vaccination}

Mr D. Ennals, for the Department of Social Services, told Mr L. Pavitt that it was too early to announce the results of the clinical trials with rubella vaccine which started in October 1967. Mr Pavitt, concerned that delays would mean exposing the population to unnecessarv risks of the disease, not least the risk of induced deafness, was told that the Joint Committee on $V$ accination and Immunization was reviewing the subject on May 13, but was unlikely to make any recommendation at this stage. (Oral answer, May 12.)

\section{European TV Satellite}

The Minister of Technology, Mr A. Wedgwood Benn. reminded the House that at the European Space Conference in November 1968 Britain agreed to participate in a European applications satellite prouramme so long as it used the most economic launcher and Britain was relieved of part of its remaining antici- pated contribution to ELDO. During this conference, the countries which decided to continue to develop a European launcher agreed to foot the extra cost. At the ELDO ministerial conference on April 15 it was agreed to reduce Britain's outstanding contribution to

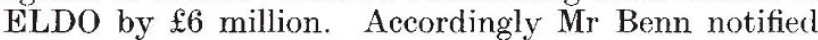
the secretary-general of the European Space Conference that Britain is willing in principle to participate in the CETS television satellite project. (Written answer, May 12.)

\section{Oral Contraception}

IN reply to a series of questions about oral contraception, Mr Richard Crossman, Secretary of State for Social Services, said that the Medical Research Council, the Family Planning Association and the Royal College of General Practitioners are all researching into the connexion between thrombosis and the pill. $\mathrm{He}$ also announced that the Health Education Council is setting up an Advisory Panel on Sex Education to educate the public in the use of all types of contraceptives. Mr Crossman said that he would like to make it 